\title{
Spinal Ewing Sarcoma Debuting with Cord Compression: Have We Discovered the Thread of Ariadne?
}

\author{
STERGIOS BOUSSIOS ${ }^{1}$, CATHERINE HAYWARD ${ }^{1}$, DEIRDRE COOKE ${ }^{1}$, \\ NIKOLAOS ZAKYNTHINAKIS-KYRIAKOU ${ }^{2}$, ALEXANDROS K. TSIOURIS ${ }^{3}$, \\ AIKATERINI A. CHATZIANTONIOU ${ }^{4}$, FOIVOS S. KANELLOS ${ }^{3}$ and AFRODITI KARATHANASI ${ }^{1}$ \\ ${ }^{1}$ Acute Oncology Assessment Unit, Medway NHS Foundation Trust, Kent, U.K.; \\ ${ }^{2}$ Leicester Diabetes Research Centre, Leicester, U.K. \\ ${ }^{3}$ Department of Biological Applications and Technology, University of Ioannina, Ioannina, Greece; \\ ${ }^{4}$ Faculty of Medicine, University of Ioannina, Ioannina, Greece
}

\begin{abstract}
Ewing's sarcoma (ES) of the spine with cord or radicular compression as an initial sign is infrequent. It is unclear, in alleviating a neurological deficit, whether decompressive laminectomy is preferred over chemotherapy. Herein, a literature review of the treatment approaches to the primary or metastatic ES of the spine has been performed. Collected data included clinical features of the patients, treatment, and outcome. There are reported 69 cases with initial presentation of cord or radicular compression of spinal cord, arising from primary or metastatic ES, treated either with initial chemotherapy and/or radiotherapy $(R T)$ $(33.33 \%, n=23)$, or decompressive surgery $(66.66 \%, n=46)$. The median age at diagnosis was 17.95 years old (range $=0.06-60)$, and 38 patients $(55.07 \%)$ were male. Eighteen $(78.26 \%)$ were initially treated with chemotherapy combined with RT, whereas 3 (13.04\%) were managed with $R T$ alone. One patient $(4.35 \%)$ received only corticosteroids, while there are not available data for the treatment of another one (4.35\%). The remaining 46 patients (66.66\%) were initially treated with decompressive surgery. Among them, 40 (57.97\%) received postoperative chemotherapy, $R T$ or combined modality therapy, whereas 6 patients (8.69\%) were not treated adjuvantly. Sixteen out of 23 patients
\end{abstract}

Correspondence to: Dr. Stergios Boussios MD, Ph.D., Consultant Medical Oncologist, Medway NHS Foundation Trust, Windmill Road, Gillingham, Kent, ME7 5NY, U.K. Tel: +30 6938625210 and +447960382149, e-mail: stergiosboussios@gmail.com and stergios.boussios@nhs.net

Key Words: Ewing's sarcoma, spinal cord compression, chemotherapy, radiotherapy, decompressive surgery, review.
(69.6\%) treated with systemic therapy, and 37 from 46 (80.43\%) of those managed with decompressive laminectomy were still alive at a mean follow-up period of 2.11 years (range=0.16-6) and 3.45 years (range=0.16-26.08), respectively. To summarize, spinal resection and reconstruction followed by adjuvant treatment reduce the risk of local recurrence, and improve long-term survival. However, ES of the spine is not a distinct clinical entity and can be either managed with chemotherapy and/or RT, similarly to other localization.

Ewing's sarcoma (ES) is defined as a bone tumor, which may occur at any site within the skeleton, but preferentially affects the diaphysis of long bones (1). It is the second most frequent bone tumor in children and adolescents (2); nearly $75 \%$ of patients are between the ages of 5 and 15 years (3). However, it may occur in extra-skeletal soft tissue in $15 \%$ of cases (4). It is most often diagnosed in people of Caucasian descent and occurs very rarely within the African American or Chinese population. ES has a slight predominance in males which accounts for $61 \%$ of the cases diagnosed (5). As with other sarcomas, genetic factors play a significant role in the growth and diagnosis of ES. At the histological level, ES appears as small, poorly differentiated tumor, with round tumor cells positive for transmembrane glycoprotein CD99 staining (6). It is characterized by rapid tumor growth and extensive bone destruction that can result in bone pain and pathological fracture (7). The pain deteriorates rapidly, intensifies at night (8), and might be accompanied by weakness and a stumbling gait. In addition to spreading to other bones throughout the body, the tumor has a tendency to spread via cortical channels to soft tissue surrounding the bone tumor. Soft tissue expansion may exist without evidence of extensive cortical 
bone destruction, and has been reported in approximately $90 \%$ of reported cases of ES (9).

Spinal cord compression can produce neurological deficits depending on the tumor location, but is often a delayed presentation. Rapidly progressing paraplegia is uncommon and a high index of suspicion is essential for diagnosis, especially in a young patient (10). Constitutional symptoms like fever and weight loss can be seen in $20 \%$ of cases; however, they are fairly uncommon (11). Serum inflammatory markers could also be elevated (12). ES is considered as systemic, requiring a combination of surgery or radiotherapy (RT) for localized control and high-intensity chemotherapy for localized and disseminated disease. Despite progress in treatment, the prognosis remains poor (13), and depends mainly on the neurological findings, the duration of symptoms once treatment has started, and on whether the disease is classified as localized or metastatic.

Only about $8 \%$ of all ES cases originate from the spinal region (11). Spinal lesions can be primary or metastatic. Currently, a uniform guideline for ES of the spine does not exist (14) and little is known about the optimal treatment strategy and therapeutic outcome. Most studies on ES involving the mobile spine are limited to case reports. The purpose of this meta-analysis is to assess the clinical profile and treatment response to either chemotherapy or surgery of ES cases debuting with neurological involvement.

\section{Materials and Methods}

The literature for spinal cord disease arising from primary or metastatic ES is reviewed in this article. Publications between 1978 and 2018 were eligible for inclusion. Original papers, review articles, and case series and reports describing either primary or metastatic ES of the vertebral column were included. Language restrictions were not used. The results were screened in a nonblinded fashion based on the title and abstract, excluding all papers not related to ES. Bibliographies of the included papers were reviewed to identify any other papers that may have been missed by the search criteria. We finally identified 69 cases of spinal ES that were retrieved from 33 relevant studies and reports in the literature. Among them, 23 patients treated primarily with chemotherapy, while 46 underwent surgery as the first line of management.

\section{Results}

Published data on spinal cord disease arising from patients with primary or metastatic ES are limited. Twenty three were initially treated with chemotherapy and/or RT, whereas 46 were primarily treated with surgery. Detailed characteristics and clinical summary of the 69 reported cases are presented in Tables I and II.

There were 38 (55.07\%) male and 31 (44.92\%) female patients, with their age ranging between 0.06 and 60 years (mean=17.95). The primary site of the tumor was cervical spine in $14(20.29 \%)$ patients, thoracic in $23(33.33 \%)$, lumbar in 17 (24.63\%), and sacrum in 15 (21.74\%) patients. Forty one out of 69 patients (59.42\%) presented with major neurological deficits consisting of imminent or complete paraplegia, whereas 17 (24.64\%) developed cauda equina syndrome with fecal and/or urinary incontinence (Table III). Paresis and bladder dysfunction presented in 25 and 17 patients $(36.23 \%$ and $24.63 \%$, respectively). An improvement in neurological findings was observed for all patients following their treatment.

Thirty six (52.17\%) of the patients remained disease-free, whereas $15(21.74 \%)$ died due to disease recurrence. Among the remaining 18 patients, 6 were alive $(8.69 \%)$ having experienced disease recurrence ranging between 1-4 times each, whereas 12 (17.39\%) were lost to follow-up. Longterm recurrences that occurred more than 12 months following initial diagnosis were observed in 14 cases (20.29\%), (Tables I and II) $(10,15,16,17,18,19,20,21)$.

Among the 46 patients who underwent decompressive surgery, 14 were paraplegic before surgery $(30.43 \%), 21$ presented with imminent paraplegia $(45.65 \%)$, and 7 with cauda equina syndrome (15.22\%) (Table III). Surgery consisted of decompressive laminectomy in 20 patients (43.48\%), whereas intralesional tumor resection without fusion was preferred for 7 tumors (15.21\%), 4 of which were located at the sacrum (Table II). External RT was used as an adjuvant treatment in 30 of the 69 cases $(43.48 \%)$, whereas in 2 patients $(2.89 \%)$ intraoperative radiation was added before spine fusion, following the guidelines of Calvo et al. (22). Adjuvant chemotherapy was applied in 32 cases (46.37\%). Eleven of the 46 operated cases were lost to follow-up. Among the remaining 35 patients, 24 (68.57\%) were still alive without evidence of recurrence at a mean follow-up of 46.38 months (range $=2-313$ ). Eleven patients developed recurrence of the tumor $(31.43 \%)$, but only 2 (5.71\%) occurred within the first year. The median overall survival (OS) in 8 patients who died $(22.86 \%)$ from the tumoral disease was 28.50 months (range=7-84), (Table II).

Among the 23 patients treated primarily with chemotherapy (Table I), 12 were alive (52.17\%) without recurrent disease, whereas 1 was lost to follow-up. Ten patients (43.47\%) developed local recurrences of the tumor, half of them within the first year $(22.72 \%)$. Finally, 7 patients $(30.43 \%)$ died; the median OS was 23.64 months (range $=2-60$ ). There were no statistically significant differences between the outcomes of the two therapeutic approaches.

Our comprehensive review focused on the compilation of data for patients with spinal ES debuting with neurological involvement. This clinical entity has a very low incidence, and no single institution would encounter enough patients to draw meaningful conclusions. One of the main limitations of this study is its retrospective nature, related to the lack of standardization of several parameters, such as follow-up period, between the different patient cohorts. Another 
Table I. Clinical summary of patients primarily treated with chemotherapy $(n=23)$.

\begin{tabular}{|c|c|c|c|c|c|c|}
\hline $\begin{array}{lr}\text { References and date } & \mathrm{Nu} \\
\text { of publication } & \mathrm{p}\end{array}$ & $\begin{array}{l}\text { Number of } \\
\text { patients }\end{array}$ & $\begin{array}{l}\text { Age/ } \\
\text { gender }\end{array}$ & $\begin{array}{l}\text { Primary } \\
\text { site }\end{array}$ & Management & $\begin{array}{l}\text { First } \\
\text { CT }\end{array}$ & Recurrence \\
\hline \multirow[t]{5}{*}{$\begin{array}{l}\text { Vázquez-García } \\
\text { B et al. (10), } 2012\end{array}$} & \multirow[t]{5}{*}{5} & $15 \mathrm{y} /$ Male & S1 & $\begin{array}{c}\mathrm{CT}+\mathrm{RT}+\text { bone } \\
\text { marrow transplant }\end{array}$ & Not reported & None (during $9 \mathrm{~m}$ of $\mathrm{FU}$ ) \\
\hline & & $15 \mathrm{y} /$ Male & L5-S2 & $\mathrm{CT}+\mathrm{RT}$ & Not reported & None (during $10 \mathrm{~m}$ of $\mathrm{FU}$ ) \\
\hline & & $15 \mathrm{y} /$ Female & $\mathrm{S} 1$ & RT & - & $1^{*}$ (death $6.5 \mathrm{~m}$ after diagnosis) \\
\hline & & $17 \mathrm{y} / \mathrm{Male}$ & S2-5 & Not reported & - & $1^{*}$ (death $11 \mathrm{~m}$ after diagnosis) \\
\hline & & $17 \mathrm{y} /$ Female & S1-2 & RT & - & Death $37 \mathrm{~m}$ after diagnosis \\
\hline \multirow[t]{11}{*}{$\begin{array}{l}\text { Mirzaei L et al. } \\
(15), 2015\end{array}$} & \multirow[t]{11}{*}{11} & $20 \mathrm{y} /$ Female & Th12-L1 & $\mathrm{CT}+\mathrm{RT}$ & EVAIA: 14 cycles & $\begin{array}{c}3 *(3.9 \mathrm{y}, 5.5 \mathrm{y} \\
6 \mathrm{y} \text { after diagnosis })\end{array}$ \\
\hline & & $16 \mathrm{y} /$ Female & Th3-6 & $\mathrm{CT}+$ Surg+RT & VIDE: 6 , VAC: 1 cycle & None \\
\hline & & $9 \mathrm{y} /$ Male & L3-5 & $\mathrm{CT}+\mathrm{RT}$ & T9 Rosen protocol & None \\
\hline & & $13 \mathrm{y} /$ Female & Th6-7 & $\mathrm{CT}+\mathrm{RT}$ & VIDE: 4 cycles & None \\
\hline & & $13 \mathrm{y} /$ Male & L5-S3 & $\mathrm{CT}+\mathrm{RT}$ & VIDE: 6 cycles & None \\
\hline & & $22 \mathrm{y} /$ Male & $\mathrm{S} 1-3$ & $\mathrm{CT}+\mathrm{RT}+$ Surg & EVAIA: 14 cycles & None \\
\hline & & $17 \mathrm{y} /$ Female & S2-4 & $\mathrm{CT}+\mathrm{RT}$ & EVAIA: 14 cycles & $1 *(3.1 \mathrm{y}$ after diagnosis $)$ \\
\hline & & $23 \mathrm{y} / \mathrm{Male}$ & S1-5 & $\mathrm{CT}+\mathrm{RT}$ & EVAIA: 14 cycles & None \\
\hline & & $14 \mathrm{y} /$ Male & $\mathrm{C} 1-5$ & $\mathrm{CT}+\mathrm{RT}+\mathrm{CT}$ & CEVAIE: 4 cycles & None \\
\hline & & $14 \mathrm{y} /$ Female & S2-3 & $\mathrm{CT}+\mathrm{RT}$ & VIDE: 14 cycles & None \\
\hline & & $15 \mathrm{y} /$ Male & L3-5 & $\mathrm{RT}+\mathrm{CT}+\mathrm{RT}$ & VIDE: 6 , VAI: 8 cycles & None \\
\hline $\begin{array}{l}\text { Ralapanawa DM } \\
\text { et al. (24), } 2015\end{array}$ & 1 & $25 \mathrm{y} /$ Female & C7-Th2 & Dexamethasone & - & $\begin{array}{l}\text { Respiratory failure and death } \\
\text { prior to oncological treatment }\end{array}$ \\
\hline $\begin{array}{l}\text { Yadav TP et al. } \\
(36), 1998\end{array}$ & 1 & $12 \mathrm{y} /$ Male & C7-Th2 & $\mathrm{CT}+\mathrm{RT}$ & VACA: 10 cycles & $1^{*}(11 \mathrm{~m}$ after diagnosis $)$ \\
\hline $\begin{array}{l}\text { Benesch M et al. } \\
(41), 1999\end{array}$ & 10.16 & $2 \mathrm{~m} / \mathrm{Male}$ & L3-S1 & $\mathrm{CT}+$ Surg+RT & EVAIA: 11 cycles & $1^{*}$ (death $2 \mathrm{~m}$ after diagnosis) \\
\hline $\begin{array}{l}\text { Theeler BJ et al. } \\
(47), 2009\end{array}$ & 1 & $28 \mathrm{y} /$ Female & Th5-7 & $\mathrm{RT}+\mathrm{CT}$ & CAV: 1 , IE: 1 cycles & None (during $2 \mathrm{~m}$ of $\mathrm{FU}$ ) \\
\hline Aydin R et al. (48), 2013 & 131 & $7 \mathrm{y} /$ Male & $\begin{array}{c}\text { Cervical } \\
\text { vertebral mass }\end{array}$ & RT & - & Not reported \\
\hline \multirow[t]{2}{*}{$\begin{array}{l}\text { Chihak MA et al. } \\
\text { (49), } 2016\end{array}$} & \multirow[t]{2}{*}{2} & $50 \mathrm{y} /$ Male & Th10-L1 & $\mathrm{CT}+\mathrm{RT}$ & VDC/IE: 6 cycles & $\begin{array}{l}3^{*}(48 \mathrm{~m}, 50 \mathrm{~m} \text {, and death } \\
60 \mathrm{~m} \text { after diagnosis })\end{array}$ \\
\hline & & $60 \mathrm{y} / \mathrm{Male}$ & L2-3 & $\mathrm{CT}+\mathrm{RT}+\mathrm{CT}$ & $\begin{array}{c}\text { IE alternating } \\
\text { with ifosfamide and } \\
\text { doxorubicin: } 3 \text { cycles }\end{array}$ & $\begin{array}{c}4^{*}(4 \mathrm{~m}, 9 \mathrm{~m}, 17 \mathrm{~m}, \text { and } \\
\text { death } 47 \mathrm{~m} \text { after diagnosis })\end{array}$ \\
\hline
\end{tabular}

*Number of recurrences; CT: chemotherapy; y: years; S: sacral; RT: radiotherapy; m: months; FU: follow-up; L: lumbal; Surg: surgery; Th: thoracal; EVAIA: etoposide (stop after 6 cycles), vincristine, doxorubicin/actinomycin-D (alternating), ifosfamide; VIDE: vincristine, ifosdamide, doxorubicin, etoposide; T9 Rosen protocol: 5 cycles of dactinomycin, cyclophosphamide, bleomycin, vincristine, methotrexate, adriamycin; C: cervical; CEVAIE, carboplatin, epirubicin, vincristine, actinomycin, ifosfamide, etoposide; VACA: vincristine, cyclophosphamide, adriamycin, actinomycin-D; CAV: vincristine, cyclophosphamide, doxorubicin; IE: ifosfamide, etoposide; VDC/IE: vincristine, doxorubicin, cyclophosphamide, ifosfamide, etoposide.

drawback of the retrospective design was that the neurological examination of the patients was sometimes incomplete. Further research is needed to identify and improve the optimal management and survival of patients diagnosed with spinal cord disease arising from primary or metastatic ES. Due to its rarity, randomised trials for assessing the relative benefits of the two available treatment modalities are extremely challenging, but could be achieved with international cooperation.

Epidemiology. ES is an uncommon neoplasm of childhood and adolescence, and accounts for only 3.5 to $14.9 \%$ of all primary bone sarcomas (23); only $8 \%$ of all cases originate from the spinal region (11). Among the reported patients with spinal ES presented with cord or radicular compression, 42 out of $69(60.87 \%)$ were 16 years old or younger (Tables I and II). The disease usually arises from the diaphysis of long bones (11), but affects also the pelvic bone (21). Commonest affected sites in order of frequency are ribs, femurs, spine, tibias, fibulas, and scapulas (24).

Primary spinal ES may arise from all levels of the spine and can be intramedullary, as well as extramedullary, either intradural or extradural. The intramedullary tumors originate from the spinal cord, while the extradural tumors might arise from vertebrae, soft tissue or spinal nerve roots. The involvement of the cauda equine region is based on the fact 
Table II. Clinical summary of patients primarily treated with surgery $(n=46)$.

\begin{tabular}{|c|c|c|c|c|c|c|}
\hline $\begin{array}{l}\text { References and date } \\
\text { of publication }\end{array}$ & $\begin{array}{l}\text { Number of } \\
\text { patients }\end{array}$ & $\begin{array}{l}\text { Age/ } \\
\text { gender }\end{array}$ & $\begin{array}{l}\text { Primary } \\
\text { site }\end{array}$ & Management & $\begin{array}{l}\text { Surgical } \\
\text { approach }\end{array}$ & Recurrence \\
\hline Vázquez-García & 11 & $12 \mathrm{y} / \mathrm{Male}$ & L4-5 & Surg+CT+RT & L1-3 decompression laminectomy & None (during $62 \mathrm{~m}$ of FU) \\
\hline B et al. (10), & & $14 \mathrm{y} /$ Female & Th7 & Surg+CT+RT & Th5-8 decompression laminectomy & None (during $87 \mathrm{~m}$ of $\mathrm{FU}$ ) \\
\hline \multirow[t]{9}{*}{2012} & & $14 \mathrm{y} /$ Female & L2-3 & Surg+CT+RT & L2-3 decompression laminectomy & None (during $62 \mathrm{~m}$ of $\mathrm{FU}$ ) \\
\hline & & $10 \mathrm{y} /$ Male & S1 & Surg & Intralesional resection & Death $27 \mathrm{~m}$ after diagnosis \\
\hline & & $13 \mathrm{y} /$ Female & C6 & $\begin{array}{c}\text { Surg+intra- } \\
\text { operative RT+RT }\end{array}$ & Intralesional resection & Death $23 \mathrm{~m}$ after diagnosis \\
\hline & & $17 \mathrm{y} /$ Male & Th11 & $\begin{array}{c}\text { Surg+intra- } \\
\text { operative RT+RT }\end{array}$ & Intralesional resection & None (during $313 \mathrm{~m}$ of $\mathrm{FU}$ ) \\
\hline & & $9 \mathrm{y} /$ Female & S1 & Surg+RT & Intralesional resection & Death $31 \mathrm{~m}$ after diagnosis \\
\hline & & $14 \mathrm{y} /$ Female & Th6 & Surg+RT & Intralesional resection & Death $13 \mathrm{~m}$ after diagnosis \\
\hline & & $5 \mathrm{y} /$ Male & S2-3 & Surg & Wide tumor resection & None (during 96 m of FU) \\
\hline & & $10 \mathrm{y} / \mathrm{Female}$ & S3-5 & Surg & Intralesional resection & None (during $49 \mathrm{~m}$ of FU) \\
\hline & & $5 \mathrm{y} /$ Female & $\mathrm{S} 1$ & Surg+RT & Intralesional resection & Death $31 \mathrm{~m}$ after diagnosis \\
\hline $\begin{array}{l}\text { Zuberi } \mathrm{J} \text { et al. } \\
(11), 2018\end{array}$ & 1 & $10 \mathrm{y} /$ Female & Th7-8 & Surg+CT & Decompression surgery & Not reported \\
\hline \multirow{4}{*}{$\begin{array}{l}\text { Mirzaei L et al. } \\
(15), 2015\end{array}$} & 4 & $11 \mathrm{~m} /$ Female & Th6-10 & Surg+CT+RT & Radical resection & None \\
\hline & & $16 \mathrm{y} /$ Female & Th10-L1 & Surg+CT & Th11-L1 laminectomy & None \\
\hline & & $21 \mathrm{y} /$ Female & L4-5 & Surg+CT & L5 laminectomy & $1 *(1.1$ y after diagnosis $)$ \\
\hline & & $13 \mathrm{y} /$ Female & Th9-11 & Surg+CT+RT & Th8-10 laminectomy & None \\
\hline \multirow[t]{2}{*}{$\begin{array}{l}\text { Scheithauer BW } \\
\text { et al. (16), } 1978\end{array}$} & 2 & $18 \mathrm{y} / \mathrm{Male}$ & L1 & Surg $+\mathrm{RT}+\mathrm{CT}$ & $\begin{array}{l}\text { L1 laminectomy with left } \\
\text { anterolateral approach }\end{array}$ & None (during $16 \mathrm{~m}$ of $\mathrm{FU}$ ) \\
\hline & & $27 \mathrm{y} /$ Female & Th4-6 & Surg+RT & Th6 laminectomy & $\begin{array}{c}2 *(3.5 \mathrm{y}, \text { and } 8.5 \mathrm{y} \\
\text { after diagnosis })\end{array}$ \\
\hline $\begin{array}{l}\text { Bemporad JA } \\
\text { et al. (17), } 1999\end{array}$ & 1 & $8 \mathrm{y} /$ Male & $\mathrm{C} 7$ & Surg+CT & $\begin{array}{l}\text { C6-7 and C7-T1 diskectomies, } \\
\text { C7 corpectomy, epidural tumor } \\
\text { resection, C6-T1 fusion with } \\
\text { anterior C6-T1 plating, } \\
\text { and halo placement }\end{array}$ & None (during $20 \mathrm{~m}$ of FU) \\
\hline $\begin{array}{l}\text { Goktepe AS } \\
\text { et al. (18), } 2002\end{array}$ & 1 & $22 \mathrm{y} /$ Male & L3 & Surg+RT+CT & $\begin{array}{l}\text { L3 total laminectomy and } \\
\text { bilateral foraminotomy }\end{array}$ & None (during $2 \mathrm{~m}$ of $\mathrm{FU}$ ) \\
\hline $\begin{array}{l}\text { Dincbas FO } \\
\text { et al. (19), } 2005\end{array}$ & 1 & $10 \mathrm{y} /$ Male & $\begin{array}{l}\text { Initially } \\
\text { irst metatarsal } \\
\text { f the left foot } \\
\text { ird recurrence } \\
\text { in Th6-7 }\end{array}$ & Surg+RT & $\begin{array}{l}\text { T6-T7 laminectomy and } \\
\text { gross total removal } \\
\text { of the tumor }\end{array}$ & $\begin{array}{l}4^{*}(4 \mathrm{y}, 5 \mathrm{y}, 6.5 \mathrm{y}, \text { and } \\
\text { death } 7 \mathrm{y} \text { after diagnosis })\end{array}$ \\
\hline Li MJ et al. (20), 2008 & 1 & $18 \mathrm{y} /$ Male & Th2-5 & Surg+RT+CT & Surgical resection of the tumour & $1 *(14 \mathrm{~m}$ after diagnosis $)$ \\
\hline \multirow[t]{4}{*}{ Zhu Q et al. (21), 2012} & 4 & $46 \mathrm{y} / \mathrm{Male}$ & $\mathrm{C} 3-6$ & $\begin{array}{l}\text { Surg+intra- } \\
\text { operative } \\
\mathrm{CT}+\mathrm{RT}+\mathrm{CT}\end{array}$ & $\begin{array}{l}\text { Resection with anterior- } \\
\text { posterior surgery }\end{array}$ & Death $12 \mathrm{~m}$ after diagnosis \\
\hline & & $27 \mathrm{y} /$ Male & C1-4 & $\begin{array}{l}\text { Surg+intra- } \\
\text { perative } \mathrm{CT}+\mathrm{RT}+\mathrm{CT}\end{array}$ & $\begin{array}{l}\text { Resection with anterior- } \\
\text { posterior surgery }\end{array}$ & $\begin{array}{c}\text { None } \\
\text { (during } 18 \mathrm{~m} \text { of FU) }\end{array}$ \\
\hline & & $27 \mathrm{y} /$ Male & C7 & $\begin{array}{l}\text { Surg+intra- } \\
\text { perative } \mathrm{CT}+\mathrm{RT}+\mathrm{CT}\end{array}$ & $\begin{array}{l}\text { Resection with anterior- } \\
\text { posterior surgery }\end{array}$ & $\begin{array}{c}\text { None } \\
\text { (during } 30 \mathrm{~m} \text { of FU) }\end{array}$ \\
\hline & & $24 \mathrm{y} /$ Male & $\mathrm{C} 5$ & $\begin{array}{c}\text { Surg+intra- } \\
\text { operative CT+CT }\end{array}$ & $\begin{array}{l}\text { Resection with } \\
\text { posterolateral surgery }\end{array}$ & $\begin{array}{c}\text { Death } 7 \mathrm{~m} \\
\text { after diagnosis }\end{array}$ \\
\hline $\begin{array}{l}\text { Electricwala AJ } \\
\text { et al. }(23), 2016\end{array}$ & 1 & $2 \mathrm{y} / \mathrm{Male}$ & L3-5 & Surg+RT+CT & $\begin{array}{l}\text { L4 decompressive } \\
\text { laminectomy }\end{array}$ & Not reported \\
\hline $\begin{array}{l}\text { Farrokhi MR } \\
\text { et al. (26), } 2014\end{array}$ & 1 & $17 \mathrm{y} /$ Female & S1-5 & Surg & $\begin{array}{l}\text { En block resection of } \\
\text { the sacrum }\end{array}$ & Not reported \\
\hline $\begin{array}{l}\text { Siami-Namini K } \\
\text { et al. }(27), 2005\end{array}$ & 1 & $15 \mathrm{y} /$ Female & Th4-7 & Surg & Decompression surgery & Not reported \\
\hline $\begin{array}{l}\text { Song X et al. } \\
(28), 2008\end{array}$ & 1 & $4 \mathrm{y} /$ Female & Th11-L4 & Surg+RT+CT & $\begin{array}{l}\text { Subtotal removal } \\
\text { of the tumour }\end{array}$ & None (during $22 \mathrm{~m}$ of $\mathrm{FU}$ ) \\
\hline $\begin{array}{l}\text { Zamzuri Z et al. } \\
(34), 2012\end{array}$ & 1 & $9 \mathrm{y} /$ Female & L4-S1 & Surg+CT & L2-S1 laminectomy & Not reported \\
\hline
\end{tabular}


Table II. Continued

\begin{tabular}{|c|c|c|c|c|c|c|}
\hline $\begin{array}{l}\text { References and date } \\
\text { of publication }\end{array}$ & $\begin{array}{c}\text { Number of } \\
\text { patients }\end{array}$ & $\begin{array}{l}\text { Age/ } \\
\text { gender }\end{array}$ & $\begin{array}{l}\text { Primary } \\
\text { site }\end{array}$ & Management & $\begin{array}{l}\text { Surgical } \\
\text { approach }\end{array}$ & Recurrence \\
\hline $\begin{array}{l}\text { Gopalakrishnan CV } \\
\text { et al. (44), } 2012\end{array}$ & 1 & $16 \mathrm{y} /$ Female & Th9 & Surg $+\mathrm{CT}+\mathrm{RT}$ & Radical tumor decompression & Not reported \\
\hline $\begin{array}{l}\text { Chihak MA } \\
\text { et al. (49), } 2016\end{array}$ & 1 & $25 \mathrm{y} /$ Male & $\mathrm{C} 4-7$ & Surg+RT+CT & $\begin{array}{l}\text { Tumor debulking, } \\
\text { instrumentation, and } \\
\text { arthrodesis from C3-T1 }\end{array}$ & None (during $20 \mathrm{~m}$ of FU) \\
\hline \multirow[t]{2}{*}{$\begin{array}{l}\text { Jamjoom A et al. } \\
(50), 1993\end{array}$} & 2 & $17 \mathrm{y} /$ Male & S1 & Surg+RT+CT & $\begin{array}{l}\text { L4-S1 laminectomy and total } \\
\text { excision of the posterior } \\
\text { part of the tumour }\end{array}$ & None (during 7 y of FU) \\
\hline & & $11 \mathrm{~m} /$ Male & C6-7 & & $\begin{array}{l}\text { C5-Th1 laminectomy and near total } \\
\text { excision of the tumour }\end{array}$ & None (during 2 y of FU) \\
\hline $\begin{array}{l}\text { Dini LI et al. } \\
(51), 2006\end{array}$ & 1 & $18 \mathrm{y} / \mathrm{Male}$ & Th12-L1 & Surg+CT+RT & $\begin{array}{l}\text { Subtotal vertebrectomy and } \\
\text { decompression with a combined } \\
\text { anterior and posterior approach }\end{array}$ & None (during $3 \mathrm{~m}$ of $\mathrm{FU}$ ) \\
\hline $\begin{array}{l}\text { Lmejjati M et al. } \\
(52), 2006\end{array}$ & 1 & $16 \mathrm{y} / \mathrm{Male}$ & Th12-L2 & Surg $+\mathrm{CT}+\mathrm{RT}$ & $\begin{array}{l}\text { Total resection with anterior } \\
\text { decompression by transthoraco- } \\
\text { phrenolaparotomy approach, } \\
\text { followed by L1 corpectomy }\end{array}$ & None (during $23 \mathrm{~m}$ of $\mathrm{FU}$ ) \\
\hline $\begin{array}{l}\text { Qureshi et al. } \\
\text { (53), } 2007\end{array}$ & 1 & $11 \mathrm{y} / \mathrm{Male}$ & $\mathrm{C} 2-4$ & Surg+RT+CT & Removal of the cervical mass & Not reported \\
\hline $\begin{array}{l}\text { Bozkurt G et al. } \\
\text { (54), } 2007\end{array}$ & 1 & $28 \mathrm{y} / \mathrm{Male}$ & $\mathrm{C} 3-5$ & Surg $+\mathrm{CT}+\mathrm{RT}$ & $\begin{array}{l}\text { C3-4 laminoplasty and } \\
\text { gross-total resection of the lesion }\end{array}$ & None (during $18 \mathrm{~m}$ of $\mathrm{FU}$ ) \\
\hline $\begin{array}{l}\text { Ban SP et al. } \\
(55), 2010\end{array}$ & 1 & 3 w/Male & Th11-L2 & Surg+CT & T11-L2 laminectomy & None (during $17 \mathrm{~m}$ of $\mathrm{FU}$ ) \\
\hline $\begin{array}{l}\text { Shankar R et al. } \\
(56), 2012\end{array}$ & 1 & $16 \mathrm{y} /$ Female & L3 & Surg+CT & L3-4 laminectomy & None (during $2 \mathrm{~m}$ of $\mathrm{FU}$ ) \\
\hline $\begin{array}{l}\text { Kannan KK et al. } \\
(57), 2015\end{array}$ & 1 & $18 \mathrm{y} /$ Male & L2-5 & Surg+CT+RT & $\begin{array}{l}\text { L3-4 laminectomy } \\
\text { with a posterior approach }\end{array}$ & Not reported \\
\hline $\begin{array}{l}\text { Kafadar C et al. } \\
(58), 2016\end{array}$ & 1 & $10 \mathrm{y} / \mathrm{Male}$ & L3 & Surg+CT & Not reported & Not reported \\
\hline $\begin{array}{l}\text { Beuriat PA et al. } \\
(59), 2017\end{array}$ & 1 & $12 \mathrm{y} /$ Female & Th2-6 & Surg+CT+RT & $\begin{array}{l}\text { C7-T2 laminoplasty and } \\
\text { T3-T6 laminectomy }\end{array}$ & Not reported \\
\hline $\begin{array}{l}\text { Eghbal K et al. } \\
(60), 2017\end{array}$ & 1 & $38 \mathrm{y} /$ Female & L1-2 & Surg & $\begin{array}{l}\text { L1-3 laminectomy and total } \\
\text { resection of the lesion }\end{array}$ & None (during $6 \mathrm{~m}$ of $\mathrm{FU}$ ) \\
\hline $\begin{array}{l}\text { Kumar Y et al. } \\
(61), 2018\end{array}$ & 1 & $11 \mathrm{y} /$ Female & Th1-4 & Surg $+\mathrm{CT}+\mathrm{RT}$ & $\begin{array}{l}\text { C7-Th4 laminectomy and } \\
\text { dorsal spine extradural } \\
\text { tumour excision }\end{array}$ & $\begin{array}{l}\text { Ambulatory patient } \\
2 \mathrm{w} \text { after the surgery }\end{array}$ \\
\hline
\end{tabular}

*Number of recurrences; Y: years; L: lumbal; m: months; Surg: surgery; CT: chemotherapy; RT: radiotherapy; m: months; FU: follow-up; Th: thoracal; S: sacral; C: cervical; w: weeks.

that it forms part of the peripheral nervous system, where the axons have become dependent on Schwann cells for the maintenance of their myelin sheaths (25).

The disease usually extends beyond the vertebral body into the posterior spinal elements and paraspinal soft tissues. Primary vertebral ES has been divided into sacral and nonsacral types, which is dictated by the different behavior of ES in these two regions in terms of response therapy and survival rates (26).

Histology. Diagnosis of ES relies on pathological assessment. Histologically, they have features of undifferentiated mesenchymal cells. Light microscopy reveals predominantly undifferentiated small tumor cells, with round, centrally located, blue hyperchromatic nuclei, diastase-digestible cytoplasmic material, and a small amount of clear cytoplasm with indistinct cellular borders $(24,27)$. Neuronal differentiation and intracytoplasmic glycogen may be present (28). A biphasic population of light and dark cells is common. Cytoplasmic vacuoles have been described in atypical ES. These tumors have larger cells as compared to those in conventional ES, exhibit greater heterogeneity, and are characterized by focal spindle cell features (27). With regards to differentiation of ES from lymphoma, the cytology identifies lymphoglandular bodies that are typical for lymphomas, but not for ES. Other poorly differentiated small- 
Table III. Clinical presentation of all patients $(n=69)$.

\begin{tabular}{lcrrrrr}
\hline Group of patients & \multicolumn{5}{c}{ Clinical presentation } \\
\cline { 2 - 6 } & Pain & Weakness & Sensory deficit & CES & IP & CP \\
\hline Primary non-surgical group (n=23) & $14(60.87 \%)$ & $7(30.43 \%)$ & $10(43.48 \%)$ & $10(43.48 \%)$ & $5(21.74 \%)$ & $1(4.35 \%)$ \\
Primary surgical group ( $\mathrm{n}=46)$ & $33(71.74 \%)$ & $22(47.82 \%)$ & $21(45.64 \%)$ & $7(15.22 \%)$ & $21(45.64 \%)$ & $14(30.43 \%)$ \\
Total (n=69) & $47(68.11 \%)$ & $29(42.03 \%)$ & $31(44.93 \%)$ & $17(24.64 \%)$ & $26(37.68 \%)$ & $15(21.74 \%)$ \\
\hline
\end{tabular}

CES: Cauda equina syndrome; IP: imminent paraplegia; CP: complete paraplegia.

round-blue-cell tumors that are included in the differential diagnosis are the neuroblastoma, and the rhabdomyosarcoma. Immunohistochemically, neuroblastoma would be positive for CD56, whereas muscle marker positivity would support a diagnosis of rhabdomyosarcoma (28).

Molecular cytogenetics. Reciprocal translocation between chromosomes 11 and 22 involving bands q24 and q12, $\mathrm{t}(11 ; 22)(\mathrm{q} 24 ; \mathrm{q} 12)$, is identified with either molecular or cytogenetic analysis in approximately $90 \%$ of ES, peripheral primitive neuroectodermal tumors, and Askin tumors (27). With this regard, it has been recognized as the diagnostic gold standard. The translocation produces a fusion gene EWS/FLI-1 that promotes tumorigenicity (4), and places the FLI-1 gene under the control of ESs promoter leading to overexpression of the FLI-1-protein. Distinct membranous glycoprotein CD99 expression is characteristic and a highly reliable positive marker for ES, but is not specific (29). Cytogenetics in conjunction with other clinicopathologic features are usually sufficient to make an accurate diagnosis (30).

Several biological pathways, such as those involving insulin-like growth factor receptor (IGFR), platelet-derived growth factor receptor (PDGFR), vascular endothelial growth factor receptor (VEGFR), Sonic Hedgehog (SHH) pathway activation, Wnt, and transforming growth factor (TGF)- $\beta$ receptor II pathway inhibition, are modulated by EWS-FLI1 activity. This leads to cancer cell proliferation, angiogenesis, immune system escape, metastatic potential, and treatment resistance that affect ES malignant phenotype $(31,32,33)$.

Clinical presentation. ESs that affect extremities present as painful, and palpable tumors. However, in cases of ES arising primarily in the spinal epidural space, back pain that could radiate to the lower limbs along with a palpable mass are the first clinical manifestations. The pain is usually relentless and progressive and does not subside with rest. In the spinal ES, the greatest source of pain is attributed to the instability of the spine to support the weight of the body, expansion of the vertebral body's cortex due to the growing mass, compression of neighboring nerve roots, pathologic fractures, spinal cord compression, and invasion of tissue surrounding the mass (34). Among the reported cases of spinal ES, 47 out of 69 patients $(68.11 \%)$ presented with back pain (Table III). In addition, weakness in the lower extremities is usual manifestation at the presentation; this was the case in 29 out of the $69(42.03 \%)$ patients reported here (Table III). Neurological deficit usually forms part of the clinical symptoms of ES of the spine; sensory disturbances, and cauda equina syndrome were presented in $31(44.92 \%)$ and $17(24.63 \%)$ out of the reported 69 patients, respectively (Table III). Kyphotic deformity could be developed at presentation. Pyogenic infection of the spine and tuberculosis are included into differential diagnosis. Herniation of the intervertebral disc should be considered besides malignancy, especially in adolescents and adults (35). Central nervous system metastasis of ES may involve either bony calvarium or brain parenchyma. Most such lesions are found to be located in an intracranial or extradural site (24).

Anemia in the onset of ES is usually indicative of widespread disease. Complete blood count could reveal leukocytosis and elevated erythrocyte sedimentation. Constitutional symptoms, such as fever, weight loss, anorexia, and fatigue have also been reported.

Diagnosis. Imaging is a vital tool in the diagnostic approach of ES. The disease is typically characterized by moth-eaten appearance with a large soft tissue mass in long bones and aggressive periosteal new bone formation with an "onion skin" appearance; nevertheless, spinal ES is not easily distinguishable (12). A computed tomography (CT) scan is more beneficial to assess periosteal extent and damage of bone. Magnetic resonance imaging (MRI), which is superior to CT, is frequently associated with a prominent soft tissue visualization (24), and evaluates potential epidural compression (12). Grossly, tumors often appear firm, gray, and friable with distinct areas of hemorrhage and necrosis (34). Most ES are hyperintense on T2WI. Widening of intervertebral foramina, isointensity on T1WI and heterogeneous enhancement can be either presented in epidural hemangioma, neurofibromatosis, metastasis, lymphoma, extra-osseous ES, and myxopapillary ependymoma (20). 
Nonetheless, imaging alone is not considered pathognomonic, and tumor biopsy is necessary for the establishment of the diagnosis of ES. The type of biopsy depends on the location of the tumor. For small tumors, such as those on the leg or arm, an excisional biopsy could be suggested. However, the performance of incisional biopsy is more frequent (34).

Other causes of compression of spinal cord that need to be ruled out, include neurenteric cyst, lipoma, meningioma, dermoid cyst, abscess, acute leukemia, malignant tumor of vertebrae and disc protrusion. The differentiation can be achieved by thorough medical history, clinical examination, imaging studies and histopathology (36).

Treatment. The treatment for ES has evolved significantly during the last decades. Historically, patients with ES who were treated with local therapy, before the era of chemotherapy, achieved survival of not more than $10 \%$. The introduction of adjuvant chemotherapy, has increased survival to at least $50 \%$ (37). Treatment of micrometastasis and shrinkage of the tumor, may expedite effective local control with negative margins by surgery (38).

Salvage surgery for residual tumor can be considered based on location and prognosis. Subtotal or partial resection should be avoided; en-bloc resection with negative tumor margins should be the surgical goal $(14,39)$. Decompressive laminectomy was performed in 20 out of the $46(43.48 \%)$ operated patients with spinal ES reported in the literature. Among them, 12 (60\%) did not experienced relapse during a median follow-up period of 36.20 months (range 2-87 months). In 7 patients $(15.21 \%)$ was implemented intralesional tumor resection without fusion; 5 of them died (71.43\%) with an achieved OS of 25 months (range 13-31 months) (Table II). For tumors that invade the vertebral body and entrap the spinal cord from its anterior side, decompressive laminectomy is not considered (40). Extensive tumor resection could lead to loss of stability of the spine, which is a major concern. This risk has been minimized by the anterior interbody fusion with or without instrumentation (10). Substantial sacral tumors may involve pelvic fixation and reconstruction. These lesions are often large prior to diagnosis, making en-bloc resection technically challenging (14). Five out of 15 reported cases of sacral tumors were treated with intralesional resection $(33.33 \%)$; among them 3 died with an OS of 29.66 month (range 2731 months) (Table II). As such, they could be considered for RT, and/or systemic therapy. Among those 15 patients with sacral tumors, 8 have been treated within this context $(53.33 \%)$; 3 died with relatively shorten OS of 18.16 months (range 6.5-37 months), whereas 1 relapsed after 37.2 months.

The most common protocols for ES involve different chemotherapy combinations with vincristine, ifosfamide, doxorubicin, and etoposide (VIDE, EVAIA) (4). Ten out of
18 patients treated with chemotherapy $(55.55 \%)$, received either combination $(15,41)$; among them, 7 were alive without evidence of recurrence $(70 \%)$ (Table I).

External RT in adjuvant setting is indicated when is not achieved either response of the disease to chemotherapy or negative surgical margins $(42,43)$. This strategy was implemented in 30 of the 69 reported cases $(43.48 \%)$. However, it should be used cautiously, as the spinal cord is sensitive to irradiation.

Theoretically, decompression surgery of symptomatic compression of the spinal cord is suggested for the prevention of major neurological deficit $(44,45)$. However, there is currently no consensus on whether this is the optimal therapeutic approach in primary spinal ES. This is obviously explained by the fact that the disease in other anatomic locations is treated with chemotherapy first. The most critical factor in avoiding primary surgery is the high chemosensitivity of the tumor, leading to reduction of the disease burden, and consequently decreasing spinal cord compression. Immediate surgical decompression, may have negative affect on future perspective of a chemosensitive disease, such as ES (45). On the other hand, upfront surgery may be considered a definitive way to decompress the spine on the presence of neurological symptoms, given that the same result is difficult achievable with chemotherapy. Definitely, local control is an important end point of primary site treatment; nevertheless, very few reports in the literature actually address this end point (46).

Prognostic factors. Favorable factors for survival in ES include age $<10$ years, tumor volume $<100 \mathrm{ml}$, response to chemotherapy, and en-bloc resection of the tumor (39). Factors indicative of more extensive disease and a worse prognosis include the presence of tumor metastasis, tumor size larger than $8 \mathrm{~cm}$, pelvic location, leukocytosis, erythrocyte sedimentation rate, resistance to chemotherapy, elevated lactate dehydrogenase, fever, and anaemia $(24,34)$. The prognosis of patients with disease arising in the spine is worse than those with tumors of the limbs but better as compared to patients with tumors arising in the pelvis (26). Histological grades have no prognostic significance (24).

\section{Conclusion}

Spinal ES presenting with spinal cord compression have a very low incidence, and only 69 cases are reported in the literature. The discussion whether to perform immediate surgical decompression in those patients is still open. Furthermore, the risk of dissemination of the disease by upfront surgery is not clear. Retrospective case series and reports underline that chemotherapy is an effective initial treatment option, even in the presence of severe and relatively acute spinal cord compression. Theoretically, 
chemotherapy reduces micrometastases and, therefore, contributes to improved survival, from a biological point of view. Neurological deficit is recovered following treatment with chemotherapy to the same extent, as compared to surgical decompression.

Randomized studies on spinal ES are not feasible due to the rarity of this manifestation and the inherent selection bias based on the variety of tumor appearance in the reported cases. The literature is also scarce regarding local control as an end point. Further research is necessary to evaluate whether spinal ES should be treated similarly to those located in other parts of the body.

\section{References}

1 Riggi N and Stamenkovic I: The biology of Ewing sarcoma. Cancer Lett 254(1): 1-10, 2007.

2 Kaatsch P: Epidemiology of childhood cancer. Cancer Treat Rev 36(4): 277-285, 2010.

3 Leeson MC, Makley JT and Carter JR: Metastatic skeletal disease in the pediatric population. J Pediatr Orthop 5(3): 261267, 1985.

4 Redini F and Heymann D: Bone tumor environment as a potential therapeutic target in Ewing sarcoma. Front Oncol 5: 279, 2015.

5 Moore DD and Haydon RC: Ewing's sarcoma of bone. Cancer Treat Res 162: 93-115, 2014.

6 Kovar H, Dworzak M, Strehl S, Schnell E, Ambros IM, Ambros $\mathrm{PF}$ and Gadner H: Overexpression of the pseudoautosomal gene MIC2 in Ewing's sarcoma and peripheral primitive neuroectodermal tumor. Oncogene 5(7): 1067-1070, 1990.

7 Lau YS, Adamopoulos IE, Sabokbar A, Giele H, Gibbons CL and Athanasou NA: Cellular and humoral mechanisms of osteoclast formation in Ewing's sarcoma. Br J Cancer 96(11): 1716-1722, 2007

8 Desai SS and Jambhekar NA: Pathology of Ewing's sarcoma/PNET: Current opinion and emerging concepts. Indian J Orthop 44(4): 363-368, 2010.

9 Hefti F, Brunner R, Freuler F, Hasler C and Jundt G: Pediatric orthopedics in practice. In: Neuro-othhopaedics [Brunner R (ed.)]. Heidelberg, Springer Medizin, p. 711, 2007.

10 Vázquez-García B, Barrios C, Villas C, San-Julian M, Maruenda JI, Alfonso M and Burgos J: Ewing's sarcoma of the spine with initial myeloradicular involvement in children and adolescents. Eur Orthop Traumatol 3: 189-194, 2012.

11 Zuberi J, Selevany M, Shahzad F, Qasem L, Saloukha F and Guerrero M: A typical presentation of Ewing sarcoma in a pediatric patient: A case report. Adv Surg Tech Proc 1(1): 8-11, 2018.

12 Dormans JP and Moroz L: Infection and tumors of the spine in children. J Bone Joint Surg Am 89(1): 79-97, 2007.

13 Ladenstein R, Pötschger U, Le Deley MC, Whelan J, Paulussen M, Oberlin O, van den Berg H, Dirksen U, Hjorth L, Michon J, Lewis I, Craft A and Jürgens H: Primary disseminated multifocal Ewing sarcoma: results of the Euro-EWING 99 trial. J Clin Oncol 28(20): 3284-3291, 2010.

14 Bacci G, Boriani S, Balladelli A, Barbieri E, Longhi A, Alberghini M, Scotlandi K, Forni C, Pollastri P, Vanel D and
Mercuri M: Treatment of nonmetastatic Ewing's sarcoma family tumors of the spine and sacrum: the experience from a single institution. Eur Spine J 18(8): 1091-1095, 2009.

15 Mirzaei L, Kaal SE, Schreuder HW and Bartels RH: The neurological compromised spine due to Ewing sarcoma. What first: surgery or chemotherapy? Therapy, survival, and neurological outcome of 15 cases with primary Ewing sarcoma of the vertebral column. Neurosurgery 77(5): 718-725, 2015.

16 Scheithauer BW and Egbert BM: Ewing's sarcoma of the spinal epidural space: report of two cases. J Neurol Neurosurg Psychiatry 41(11): 1031-1035, 1978.

17 Bemporad JA, Sze G, Chaloupka JC and Duncan C: Pseudohemangioma of the vertebra: an unusual radiographic manifestation of primary Ewing's sarcoma. AJNR Am J Neuroradiol 20(10): 1809-1813, 1999.

18 Goktepe AS, Alaca R, Mohur H and Coskun U: Paraplegia: an unusual presentation of Ewing's sarcoma. Spinal Cord 40(7): 367-369, 2002.

19 Dincbas FO, Oksuz DC, Atalar B, Dervisoğlu S, Kocer N, Mandel NM and Koca S: Epidural metastasis of Ewing's sarcoma: a rare localisation. J BUON 10(2): 281-284, 2005.

$20 \mathrm{Li}$ MJ, Pan ST and Cheng C: MRI of primary spinal Epidural primitive neuroectodermal tumor: a case report. Chin J Radiol 33: 91-95, 2008.

21 Zhu Q, Zhang J and Xiao J: Primary dumbbell-shaped Ewing's sarcoma of the cervical vertebra in adults: Four case reports and literature review. Oncol Lett 3(3): 721-725, 2012.

22 Calvo FA, Ortiz de Urbina D, Sierrasesúmaga L, Abuchaibe O, Azinovic I, Antillon F, Santos M and Cañadell J: Intraoperative radiotherapy in the multidisciplinary treatment of bone sarcomas in children and adolescents. Med Pediatr Oncol 19(6): 478-485, 1991.

23 Electricwala AJ and Electricwala JT: Primary Ewing's sarcoma of the spine in a two-year-old boy. Case Rep Orthop 2016: 8027137, 2016.

24 Ralapanawa DM, Jayawickreme KP, Ekanayake EM and Kumarihamy KW: Spinal intradural metastasis from scapular Ewing sarcoma. BMC Res Notes 8: 298, 2015.

25 Kumar R, Reddy SJ, Wani AA and Pal L: Primary spinal primitive neuroectodermal tumor: case series and review of the literature. Pediatr Neurosurg 43(1): 1-6, 2007.

26 Farrokhi MR, Ranjbar F, Ali Mashari M and Ardeshiri M: Primary Ewing sarcoma of the sacrum. Jentashapir J Health Res 5(1): 509-512, 2014.

27 Siami-Namini K, Shuey-Drake R, Wilson D, Francel P, Perry A and Fung KM: A 15-year-old female with progressive myelopathy. Brain Pathol 15(3): 265-267, 2005.

28 Song X, Choi J, Rao C, Nallu S and Nicastri AD: Primary Ewing sarcoma of lumbar spine with massive intraspinal extension. Pediatr Neurol 38(1): 58-60, 2008.

29 Mobley BC, Roulston D, Shah GV, Bijwaard KE and McKeever PE: Peripheral primitive neuroectodermal tumor/Ewing's sarcoma of the craniospinal vault: case reports and review. Hum Pathol 37(7): 845-853, 2006.

30 Burchill SA: Ewing's sarcoma: diagnostic, prognostic, and therapeutic implications of molecular abnormalities. J Clin Pathol 56(2): 96-102, 2003.

31 Erkizan HV, Uversky VN and Toretsky JA: Oncogenic partnerships: EWS-FLI1 protein interactions initiate key pathways of Ewing's sarcoma. Clin Cancer Res 16(16): 40774083, 2010. 
32 Jully B, Vijayalakshmi R, Gopal G, Sabitha K and Rajkumar T: Junction region of EWS-FLI1 fusion protein has a dominant negative effect in Ewing's sarcoma in vitro. BMC Cancer 12: 513, 2012.

33 Tosso PN, Kong Y, Scher L, Cummins R, Schneider J, Rahim S, Holman KT, Toretsky J, Wang K, Üren A and Brown ML: Synthesis and structure-activity relationship studies of small molecule disruptors of EWS-FLI1 interactions in Ewing's sarcoma. J Med Chem 57(24): 10290-10303, 2014.

34 Ravindra VM, Eli IM, Schmidt MH and Brockmeyer DL: Primary osseous tumors of the pediatric spinal column: review of pathology and surgical decision making. Neurosurg Focus 41(2): E3, 2016.

35 Zamzuri Z, Mohd Adham SY, Saufi MA, Azian AA and Fadhli M: Primary Ewing's sarcoma of the lumbosacral spine: A case report. The International Medical Journal Malaysia 11(1): 47-50, 2012.

36 Yadav TP, Singh RP, Gupta VK, Chaturvedi NK and Prasad CV: Paravertebral extraosseous Ewing's sarcoma. Indian Pediatr 35(6): 557-560, 1998.

37 Bernstein M, Kovar H, Paulussen M, Randall RL, Schuck A, Teot LA and Juergens H: Ewing's sarcoma family of tumors: current management. Oncologist 11(5): 503-519, 2006.

38 Subbiah V, Anderson P, Lazar AJ, Burdett E, Raymond K and Ludwig JA: Ewing's sarcoma: standard and experimental treatment options. Curr Treat Options Oncol 10(1-2): 126-140, 2009 .

39 Boriani S, Amendola L, Corghi A, Cappuccio M, Bandiera S, Ferrari S, Picci R, Difiore M and Gasbarrini A: Ewing's sarcoma of the mobile spine. Eur Rev Med Pharmacol Sci 15(7): 831$839,2011$.

40 Parikh SN and Crawford AH: Orthopaedic implications in the management of pediatric vertebral and spinal cord tumors: a retrospective review. Spine (Phila Pa 1976) 28(20): 2390-2396, 2003.

41 Benesch M, Urban C, Lackner H, Kerbl R, Schwinger W, Beham-Schmid C, Ratschek M and Oberbauer R: Atypical extraosseous Ewing sarcoma of the spinal canal with bone marrow involvement in a two-month-old boy. Med Pediatr Oncol 2(6): 471-473, 1999.

42 Ludwig JA: Ewing sarcoma: historical perspectives, current state-of-the-art, and opportunities for targeted therapy in the future. Curr Opin Oncol 20(4): 412-418, 2008.

43 Grier HE, Krailo MD, Tarbell NJ, Link MP, Fryer CJ, Pritchard DJ, Gebhardt MC, Dickman PS, Perlman EJ, Meyers PA Donaldson SS, Moore S, Rausen AR, Vietti TJ and Miser JS: Addition of ifosfamide and etoposide to standard chemotherapy for Ewing's sarcoma and primitive neuroectodermal tumor of bone. N Engl J Med 348(8): 694-701, 2003.

44 Gopalakrishnan CV, Shrivastava A, Easwer HV and Nair S: Primary Ewing's sarcoma of the spine presenting as acute paraplegia. J Pediatr Neurosci 7(1): 64-66, 2012.

45 Vogin G, Helfre S, Glorion C, Mosseri V, Mascard E, Oberlin O and Gaspar N: Local control and sequelae in localised Ewing tumours of the spine: a French retrospective study. Eur J Cancer 49(6): 1314-1323, 2013.

46 Donaldson SS: Ewing sarcoma: radiation dose and target volume. Pediatr Blood Cancer 42(5): 471-476, 2004.
47 Theeler BJ, Keylock J, Yoest S and Forouhar M: Ewing's sarcoma family tumors mimicking primary central nervous system neoplasms. J Neurol Sci 284(1-2): 186-189, 2009.

48 Aydin R, Bilgici MC and Dagcinar A: A very rare cause of neck pain: primary Ewing sarcoma of the axis. Pediatr Emerg Care 29(11): 1197-1200, 2013.

49 Chihak MA, Ahmed SK, Lachance DH, Nageswara Rao AA and Laack NN: Patterns of failure and optimal radiotherapy target volumes in primary intradural extramedullary Ewing sarcoma. Acta Oncol 55(8): 1057-1061, 2016.

50 Jamjoom A, Ur-Rahman N, Hafeez MA and Jamjoom ZA: Primary Ewing sarcoma of the spine: Report of two cases. Ann Saudi Med 13(6): 563-566, 1993.

51 Dini LI, Mendonça R and Gallo P: Primary Ewings sarcoma of the spine: case report. Arq Neuropsiquiatr 64(3A): 654-659, 2006.

52 Lmejjatia M, El Attarb H, Layadia F, Belaabidiab B and Ait Ben Alia S: Primary Ewing sarcoma of the vertebral column: Case report and literature review. Journal of Pediatric Neurology 5: 251-254, 2007.

53 Qureshi AA, Qureshi GA and Hassan M: A case of Ewing's sarcoma involving cervical spine. American-Eurasian Journal of Scientific Research 2(1): 57-59, 2007.

54 Bozkurt G, Ayhan S, Turk CC, Akbay A, Soylemezoglu F and Palaoglu S: Primary extraosseous Ewing sarcoma of the cervical epidural space. Case illustration. J Neurosurg Spine 6(2): 192, 2007.

55 Ban SP, Park SH, Wang KC, Cho BK, Phi JH, Lee JY and Kim SK: Congenital paraspinal Ewing sarcoma family of tumors with an epidural extension. J Clin Neurosci 17(12): 1599-1601, 2010.

56 Shankar R, Rao A, Ballal C and Naik R: Primary Ewings sarcoma of the lumbar spine presenting as cauda equina syndrome. The Internet Journal of Spine Surgery, Volume 6 Number 2, 2012. http://ispub.com/IJSS/6/2/14445

57 Kannan KK, Sundarapandian RJ and Surulivel VJ: Unusual presentation of a primary Ewing's sarcoma of the spine with paraplegia: A case report. J Clin Diagn Res 9(3): RD01-RD03, 2015.

58 Kafadar C, Ulusoy OL, Ozturk E and Mutlu A: Primary Ewing sarcoma of the lumbar spine presenting as cauda equina syndrome in a pediatric patient. Spine J 16(9): e593-e594, 2016.

59 Beuriat PA, Melloul S, Galmiche L, Cristofori I, Zerah M and Beccaria K: Acute isolated paraplegia revealing an Ewing sarcoma of the thoracic spine. J Pediatr Hematol Oncol 39(8): e479-e482, 2017.

60 Eghbal K, Dehghanian AR and Ghaffarpasand F: Lumbosacral epidural primitive neuroectodermal tumor (PNET): Case report and literature review. Turk Neurosurg, 2017, doi: 10.5137/10195149.JTN.20111-17.0. [Epub ahead of print]

61 Kumar YNNT and Rajan VTT: A rare case of acute paraplegia: primary Ewing's Sarcoma of dorsal spine. Int Surg J 5(5): 19271930, 2018.

Received August 13, 2018

Revised September 14, 2018

Accepted September 17, 2018 